\title{
Yumurta Kabuğu Takviyeli Polimer Kompozitlerin Mekanik Davranışının İncelenmesi
}

\author{
Mehmet Emin DENİ ${ }^{1 *}$, Abdurrahim GÜNEŞ² \\ ${ }^{1}$ Batman Üniversitesi, Makina Mühendisliği Bölümü, 72100, Batman, Türkiye \\ ${ }^{2}$ Batman Üniversitesi, Fen Bilimleri Enstitüsü, 72100, Batman, Türkiye \\ (ORCID: 0000-0003-1898-1161) (ORCID: 0000-0003-4653-8888)
}

\begin{abstract}
Öz
Bu çalışmada, RTV 2 (İki Kimyasal Bileşenli, Oda Sıcaklığında Donan) silikon kalıplara döküm yoluyla üretilmiş yumurta kabuğu takviyeli epoksi esaslı kompozit numunelerin mekanik davranışları incelenmiştir. Test numuneleri, saf epoksi ve epoksi reçineye ağırlık oranının \%5, \%10, \%20, \%30 ve \%40 yumurta kabuğu tozu takviye edilerek ASTM-D638 ve ASTM-D790 standartlarına uygun olarak hazırlanmıştır. Daha sonra bu kompozit numuneler, çekme ve üç nokta eğilme testlerine maruz bırakılmıştır. Yapılan testler sonucunda en iyi çekme mukavemeti yumurta kabuğu tozunun ağırlık oranının \%5 takviyesinde elde edilmiştir. Takviye elemanın ağırlık oran1 \%5'ten \% 40 'a artırılırken çekme mukavemetinde çok ciddi düşüşler gözlemlenmiştir. Eğilme davranışı için yapılan üç nokta eğilme testlerinde ise yumurta kabuğu tozunun ağırlıça \%20 takviye oranında kullanılması ile en yüksek mukavemet elde edilmiştir. Takviye elemanının ağırlık oranı \%20'den fazla eklendiğinde kompozit numunenin eğilme mukavemetinde düşüşler meydana gelmiştir. Sonuç olarak yumurta kabuğu takviyeli polimer esaslı kompozit numunelerin çekme ve eğilme davranışlarının ağırlıkça takviye oranına göre önemli şekilde değiştiği görülmüştür.
\end{abstract}

Anahtar kelimeler: Çekme testi, Epoksi reçine, Üç nokta eğilme testi, Yumurta kabuğu.

\section{Investigation of Mechanical Behavior of Egg Shell Reinforced Polymer Composites}

\begin{abstract}
In this study, mechanical behavior of eggshell reinforced composite specimens which is produced by casting into RTV 2 (Two Chemical Componented Room Temprature Vulcanizing) silicone molds based on epoxy was investigated. Test specimens were prepared by reinforcing 5\%,10\%, 20\%, 30\% and 40\% eggshell powder by weight to epoxy and pure epoxy resin according to ASTM-D638 and ASTM-D790 standards. After that these composite specimens were subjected to tensile and three-point bending tests. In the results of the tests, the best tensile strength was obtained by reinforcing $5 \%$ of the weight ratio of eggshell powder. But, increasing the weight ratio from $5 \%$ to $40 \%$ very significant reductions in tensile strength were observed. In the three-point bending tests for the bending behavior, the highest strength was obtained in $20 \%$ by weight reinforcement of eggshell powder. Adding more than $20 \%$ of the weight ratio of the reinforcing element, the bending strength of the composite specimens has been decreased. As a result, it has been observed that the tensile and bending behavior of eggshell reinforced composite specimens based on polymer have been significantly changed according to the reinforcement ratio by weight.
\end{abstract}

Keywords: Tensile test, Epoxy resin, Three-point bending test, Eggshell.

\section{Giriş}

Günümüzde gelişen teknoloji ve endüstriden kaynaklanan rekabet ve yeryüzü kaynaklarının hızlı tüketilmesi sonucu olarak alternatif malzemelere yönelme ihtiyacı doğmuştur. Atık malzemelerin geri dönüşümü veya bir amaç doğrultusunda istenilen özellikleri kazandırmak için farklı malzemelerin bir

*Sorumlu yazar: mehmetemin.deniz@batman.edu.tr

Geliş Tarihi: 06.12.2020, Kabul Tarihi: 19.04.2021 
araya getirilmesiyle yeni malzemeler oluşturulmak gibi yollara başvurulmuştur [1]. Bu çalışmalar neticesinde atık malzemelerin geri dönüşümü ve kompozit malzemeler imalat sektöründe oldukça önemli bir yer tutmaktadır. İki veya daha fazla malzemenin bir araya getirilmesi sonucu istenilen özelliklere ve mekanik dayanıma sahip malzemelerin üretilmesi amaçlanmıştır. Ülke genelinde her yıl yaklaşı 16 milyar tane yumurta tüketilmektedir. Yumurta kabuğunun ortalama ağırlığ 6 gr ve buna bağlı olarak tonlarca çevreyi kirletici yumurta kabuğu atı̆gı oluşmaktadır. Oluşan bu yumurta kabuğu atıkları zamanla çevreyi kirletici ve tehlikeli bir madde haline gelmektedir. Aynı zamanda rahatsız edici kokular da yaymakla beraber doğada yok olma süreleri oldukça zaman almakta ve yaşam alanlarımız için tehdit haline gelebilmektedir. Yumurta zarının içerisinde bulunan yüksek miktardaki protein çürüyerek zehirli hale gelmekte ve etrafa kötü kokular yaymaktadır. İnsan sağlığını tehdit eden bu atıkları bertaraf etmek oldukça zor ve maliyetli olduğundan değerlendirilmesi gereken bir kaynak malzemesi haline gelmiştir. Günümüzde birçok ülkede yumurta kabuğu atığı ve yumurta kabuğunun içerisindeki protein içerikli ince zar ile kozmetik ve gıda alanında kullanılan ürünler üretilebilmektedir. Ve böylelikle doğal kaynaklar korunup atık miktarı azaltılabilir. Ayrıca enerji tasarrufu ve ekonomik fayda sağlanmış olur. Mevcut çalışmanın önemine odaklanmak amacıyla konuyla ilgili daha önce yapılmış bazı araştırmalar aşağıda verilmiştir.

Kompozit malzemelerin dolguları genellikle katı halde bulunur ve polimer matrisi ile karışmaz. Dolgu maddeleri, polimerlerin mekanik ve fiziksel özelliklerini geliştirmek için farklı oranlarda kullanılmaktadır. Dolgu maddeleri, lifli ve levha benzeri şekillerde düzensiz malzemeler olarak tanımlanabilir [2]. Günümüzde dolgu maddeleri esas olarak, termal stabilite, alev geciktirici ve dayanım gibi çeşitli polimerlerin özelliklerini geliştirmek için kullanılmaktadır [3]. İnorganik dolgular (oksitler, hidroksitler, tuzlar, silikatlar ve madenler) polimerlerin termal genleşme ve kalıp büzülmesini azaltırken lifli dolgular (grafit ve karbon, doğal ve sentetik polimerler) ise polimerin erime viskozitesini azaltmaktadır. Organik dolgu maddeleri, bitki ve hayvanlardan elde edilen atık maddelerin geri dönüşümü ile üretilebilir. Organik dolgu maddeleri genel olarak düşük yoğunluk ve düşük maliyetli olduklarından polimer esaslı kompozit malzemeler için kullanılmaya uygundurlar. Nawang ve ark. [4] tarafından nişasta dolgulu polietilen kompozit malzemelerin mekanik özellikleri araştırılmıştır. Artan nişasta oranına bağlı olarak kopma mukavemeti ve kopma uzaması değerlerinin azaldığı ifade edilmiştir. İnorganik dolgu maddesi olarak kullanılan mineral dolgular, genel olarak belirli parçacık boyutlarına göre ögütülerek kullanılmaktadır. Yaygın bir şekilde kullanılan kalsiyum karbonat, çeşitli polimer reçinelerle uyumlu ve ekonomiktir. Adeosun ve ark. [5] farklı oranlarda kalsiyum karbonat dolgu parçacıkların ilavesinde polietilen esaslı kompozit malzemelerin mekanik ve fiziksel etkisini araştırmıştır. Kalsiyum karbonat yüzdesinin artırılmasıyla eğilme gerilmesinin de arttığı görülmüştür. Polimer esaslı kompozit malzemelerin özelliklerinin geliştirilmesi için en yaygın kullanılan inorganik dolgu maddeleri cam, alüminyum oksit $\left(\mathrm{Al}_{2} \mathrm{O}_{3}\right)$, magnezyum hidroksit $\left(\mathrm{Mg}(\mathrm{OH})_{2}\right)$, kalsiyum karbonat $\left(\mathrm{CaCO}_{3}\right)$ parçacıkları ve tabakalı silikatlardır. Kalsiyum karbonat parçacıklarıyla doldurulmuş epoksi reçinenin daha yüksek stabilite ve mekanik dayanıma sahip olduğu He ve ark. [6] tarafindan tespit edilmiştir. Yumurta kabuğunun çevre kirliliği üzerinde oluşturduğu etkiyi azaltmak için çeşitli uygulamalar geliştirilmiştir. Genellikle toz haline getirilerek kullanılan yumurta kabuğu iyi bir doğal kalsiyum kaynă̆ 1 olabilir. Günümüzde yumurta kabuğu, çeşitli uygulamalarda katk1 maddesi veya hammadde olarak kullanılmaktadır. Yumurta kabuğunun kullanım alanları özellikle tıbbi ve kozmetik sektörleridir. Sınırlı kemik kusurlarının doldurulması ve kemik büyütme işlemleri için yumurta kabuğu tozu, iyi bir katk1 maddesi olarak tercih edilmektedir. Hayvan yemi için katkı maddesi olarak kullanıldığını ifade eden Yoo ve ark. [7], ayrıca yüksek kalsiyum, magnezyum ve fosfor içeriğine sahip yumurta kabuğu, gübre olarak kullanılabileceğini de ifade etmiştir. Mohammadi ve ark. [8], yumurta kabuğu kemik onarımı ve organ nüfuzunda kullanılabilir olduğunu göstermiştir. Kalsiyum bakımından zengin olan yumurta kabuğu tozu, insan vücudunun kalsiyum ihtiyacını karşılamak için belirli oranlarda un ilave edilerek ekmek üretiminde kullanılabilir. Yumurta kabuğu tozu ekmeklerin sertlik değerini düşürdüğü ve ekmeğin hacminde artışa neden olduğu görülmüştür [9].

Atık ofis kâğıtları ve yumurta kabuklarından elde edilen kalsiyum karbonat ile yazı tabı kâğıdı üretimi Kıllı ve ark. [10] tarafından çalışılmıştır. Piyasada üretilen yazı kâğıdı tabı ile aynı optik özelliklerde ve yırtılma indeksinin daha yüksek olduğu belirtilmektedir. Ve maden kaynaklarından elde edilen kalsiyum karbonata göre çok daha az maliyetle imal edilebildiği görülmüştür. Wei ve ark. [11], biyo-dizel üretimi için katı katalizör üzerine yaptıkları çalışmada, düşük maliyetli katalizör olarak yumurta kabuğu atığını kullanmıştır. Yumurta kabuğu kalsinasyonu ile yüksek aktiflik elde etmişlerdir. 
Biyo-dizel üretiminde katı katalizör olarak yumurta kabuğunun kullanılması, geri dönüşüm için maliyet ve çevresel etkileri önemli ölçüde azaltacağına yer verilmiştir. Yumurta kabuğunun düşük maliyetli sorbent bileşenine emdirilmesi üzerine Chojnacka [12] yaptığı araştırmada, ezilmiş yumurta kabuklarının diğer emici maddelerle karşılaştırıldığında iyi emilim kapasitesine sahip olduğunu görmüştür.

Kompozit malzeme üretiminde yumurta kabuğu tozu çeşitli amaçlar doğrultusunda, matris malzemesine ilave edilmesi üzerine araştırmalar yapılmıştır. Yapılan bu çalışmalarda, yumurta kabuğu tozu kompozit malzeme üzerinde mekanik dayanım, 1sı ve elektriksel yalıtım, yanma ve tutuşma hızı, su alma oranı, yüzey pürüzlülüğü gibi parametrelerin incelenmesi hedeflenmiştir. Yumurta kabuğu tozu ilavesinde, kompozit malzemenin ateşe karşı direncinin artığı, yanma ve tutuşma hızı ise düşmüştür. Kompozit malzemenin su alma özelliği de azalmıştır. Kompozit malzemede, yumurta kabuğu tozu oranının artırılmasıyla çekme dayanımının arttığı ve belirli bir orandan sonra çekme dayanımı da azalmıştır. Ayrıca kopma uzama değeri ve eğilme direnci değerinde de azalmaya neden olmaktadır. Kompozit malzemede yumurta kabuğu tozu oranı arttıkça sertlik değerinin arttı̆̆ görülmüştür [13]. Farklı oranlarda eklenen yumurta kabuğu takviyeli epoksi matris ile üretilmiş, kompozit malzemelerin mekanik özellikleri Shashir ve ark. [14] tarafından araştırılmıştır. Bu araştırmada yumurta kabuğunun $\% 20$ oranında eklenmesi ile yapılan deneylerde maksimum eğilme dayanımı ve sertliğin elde edildiği belirlenmiştir. Yumurta kabuğu tozu, silisyum karbür ve alüminyum oksit takviyeli, alüminyum matrise sahip kompozit malzemelerin dayanımı incelenmiştir. Yapılan çalışmada, yazarlar takviye elemanlarının ağırlıkça yüzde oranında eklenmesiyle çekme ve akma gerilmesinin belirli bir orana kadar arttığını ve daha sonra azaldığını belirtmektedirler. Yumurta kabuğu tozunun, alüminyum oksit ve silisyum karbüre nazaran çekme ve akma gerilmelerinde daha az etkiye sahip olduğu gözlemlenmiştir [15]. Poliüretan köpük malzemesine farklı oranlarda yumurta kabuğu tozu eklenerek 1sı iletim katsayısı ve basma dayanımı Gürlek ve ark. [16] tarafından incelenmiştir. Poliüretan köpük malzemesine farklı oranlarda eklenen yumurta kabuğu tozu, basma dayanımını aşamalı artırdığını ve 1sı iletim katsayısını çok az artırdığını tespit etmişlerdir. Düşük yoğunluklu polietilen/yumurta kabuğu tozu kompozit malzemelerinin mekanik özelliklerine kimyasal modifikasyonun izoftalik asit ve yumurta kabuğu tozunun \%5-25 oranlarında katılması araştırılmışır [17]. Kompozit malzemenin, yumurta kabuğu tozu içeriğinin artmasıyla kopma uzaması ve mukavemetinin düştüğü görülmüştür. Yazarlar, düşük yoğunluklu polietilen matrisi ile yumurta kabuğu tozu parçacıkların zayıf yapışma durumu oluşturduğunu savunmuşlardır. Raghavendra ve ark. [18] tarafindan yumurta kabuğu nano partikülleri takviyelendirilmiş epoksi esaslı biyo kompozitlerin mekanik ve tribolojik özellikleri çalışmıştır. Yazarlar, kabuğun epoksi polimerlerin çekme dayanımında \%117, eğilme dayanımında \%87 ve erozyon direncinde \%67.58 oranında artırdığını belirlemiştir. Polimer kompozit malzemelerin bazı özelliklerini iyileştirmek için düşük maliyetli biyo-fiberler kullanılmaktadır. $100 \mu \mathrm{m}$ parçacık boyutuna sahip yumurta kabuğunun \%5'ten \%20' ye kadar artırımlı şekilde epoksi reçineye eklenmesi ile elde edilen numuneler sertlik, darbe, basma, çekme ve eğilme testlerine maruz bırakılmıştır [19]. Özellikle yumurta kabuğunun geleneksel takviye elemanlarına alternatif olarak kullanılabileceği görülmüștür. Yapılan testler sonucunda elde edilen maksimum dayanım değerleri çekme için \%5, eğilme için \% 15 , basma için $\% 20$, darbe için $\% 5$ ve sertlik direnci için $\% 20$ ağırlık oranında yumurta kabuğu kullanılarak elde edilmiş̧ir. Asha ve Sekhar [20] yaptıkları çalışmada, daha iyi basma, darbe ve çekme dayanımları elde etmek için yumurta kabuğu, poliamid ve naylon bileşenlerini kullanmıştır. Bu bileşenlerin farklı oranlarda kullanımı ile elde edilen kompozitler çeşitli otomotiv parçalarının üretiminde kullanılmaktadır. Yumurta kabuğunun ağırlıkça oranı artırıldıkça çekme dayanımı, eğilme dayanımı ve darbe dayanımı artmıştır. $100 \mu \mathrm{m}$ ve $150 \mu \mathrm{m}$ parçacık boyutunda hazırlanmış yumurta kabuklarının \%10-40 ağırlık oranlarında cam/epoksi kompozitler için takviyelendirici olarak kullanılması ile elde edilen numuneler çekme ve basma testlerine maruz bırakılmıştır [21]. Yumurta kabuğunun $100 \mu \mathrm{m}$ parçacık boyutunda $\% 10$ ağırlık oranında kullanımı ile numunelerin çekme dayanımında $\% 18$ ve basma dayanımında ise \%30 iyileştirme gözlemlenmiştir. Golakiya [22] çalışmasında, yumurta kabuğu ağırlık oranı $\% 5$ 'ten $\% 20$ 'e artırıldığında çekme ve eğilme dayanımlarının düştügünü görmüsstür. Genel olarak $20 \mu \mathrm{m}$ parçacık boyutlu kompozit numunelerin $32 \mu \mathrm{m}$ parçacık boyutlu olanlardan daha iyi mekanik özellikler gösterdiği belirlenmiştir.

Yapılan çalışmalarda organik ve inorganik dolgu malzemelerinin polimer matrislerin içine katılarak çeşitli uygulama alanlarında kullanılabileceğini ve bu şekilde çevre temizliğine katkı sağlanabileceği görülmüştür. Bu çalışmalara katkı sunmak ve literatür genişliği sağlamak amacı ile bu 
makale hazırlanmıştır. Çalışmada, farklı mikro parçacık boyutlarındaki yumurta kabuğu tozu farklı ağırlık oranlarında epoksi reçineye ilave edilmiştir. Daha sonra hazırlanan numuneler çekme ve üç nokta eğilme testlerine maruz bırakılmıştır. Böylece epoksi reçinenin çekme ve eğilme mekanik özellikleri üzerine kabuk tozu boyutu ve ağırlık oranının etkisi incelenmiştir.

\section{Materyal ve Metot}

\subsection{Yumurta Kabuğunun Elde Edilmesi}

Tavuk yumurtasının ortalama ağırlığı 60-80 gr gelmekte ve bu ağırlığın yaklaşık olarak \% 6-8'ini oluşturan yumurta kabuğu $0.2 \mathrm{~mm}-0.4 \mathrm{~mm}$ kalınlığında olup oldukça sert bir yapıya sahiptir. Bir tavuğun yumurta kabuğunun ağırlı̆g 1 3-6 gr arasında gelmektedir. Marketlerde satılan fabrikasyonla elde edilmiş yumurtaların kabukları suda yüzdürme metodu ile yumurta zarı ve diğer maddelerden arındırılarak 72 saat güneşte kurutulmaya bırakılmıştır. Daha sonrasında Şekil 1'de verilen şematik gösterime göre numune üretimi için kullanılacak olan yumurta kabuklarının mikro parçacık seviyede parçalanma işlemi Retsch RM200 marka küçük taş öğütücü cihazı kullanıldı. Elle küçük parçalara ayrılmış yumurta kabuğu, ögütücüye eklenerek sabit devirde 10 dakika boyunca öğütüldü. Gerekli mikro parçacık boyutlarında kabuk tozlarını temin etmek için Şekil 1'de verilen $63 \mu \mathrm{m}, 75 \mu \mathrm{m}$ ve $106 \mu \mathrm{m}$ delik boyutlu elekler kullanıldı. İstenilen boyut için gerekli toz miktarı temin edilinceye kadar işlemler tekrarlandi.

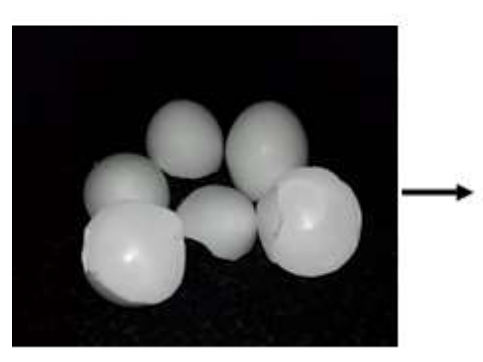

Yumurta kabukları

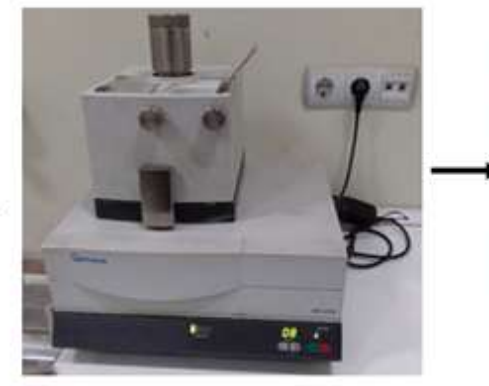

Öğütme ișlemi

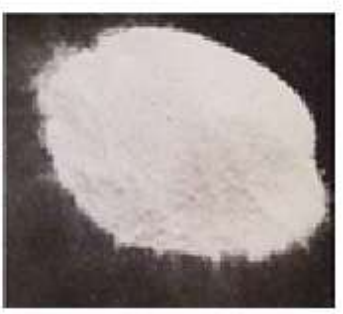

Kabuk tozu

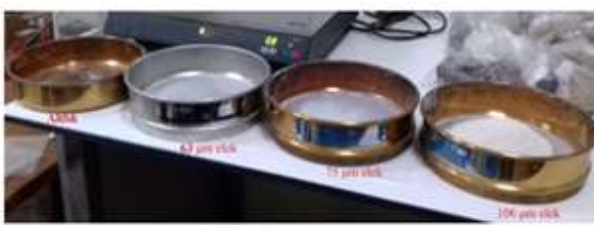

Eleme ișlemi

Şekil 1. Yumurta kabuğu elde edilme işleminin safhaları

ASTM-D638 ve ASTM-D790 standartlarına uygun olarak üretilen numuneler için 339.27 gr yumurta kabuğu tozu kullanılmıştır. Yumurta kabuk tozları $106 \mu \mathrm{m}, 75 \mu \mathrm{m}$ ve $63 \mu \mathrm{m}$ parçacık boyut parametreleri dikkate alınarak ihtiyaç duyulan kabuk tozu miktarları hesaplanmıştır. Her bir parametreye bağlı kullanılan yumurta kabuğu tozları Tablo 1'de verilmiştir.

Tablo 1. Üç nokta eğilme ve çekme testleri için gerekli yumurta kabuk tozu miktarları

\begin{tabular}{|c|c|c|}
\hline \multicolumn{1}{|c|}{ Test } & Çekme test numuneleri & Üç nokta eğilme test numuneleri \\
\hline $\mathbf{1 0 6 \mu \mathrm { m }}$ & $45.36 \mathrm{gr}$ & $67.73 \mathrm{gr}$ \\
\hline $\mathbf{7 5 \mu \mathrm { m }}$ & $45.36 \mathrm{gr}$ & $67.73 \mathrm{gr}$ \\
\hline $\mathbf{7 5 \mu \mathrm { m }}$ & $45.36 \mathrm{gr}$ & $67.73 \mathrm{gr}$ \\
\hline Toplam & $\mathbf{1 3 6 . 0 8} \mathbf{~ g r}$ & $\mathbf{2 0 3 . 1 9} \mathbf{~ g r}$ \\
\hline
\end{tabular}




\subsection{Epoksi Reçine ve Sertleştirici}

$\mathrm{Bu}$ çalışmada, kompozit numune üretiminde, LR300 PROPOX epoksi reçine ve LH300 PROPOX sertleştirici kullanılmıştır. Üretimi gerçekleştirilen bütün numuneler için sertleştirici ve epoksi oranı 1/3 olarak seçilmiştir. Üretimi gerçekleştirilen kompozit numuneler için kullanılan epoksi+sertleştirici seti Şekil 2'de gösterilmiştir.

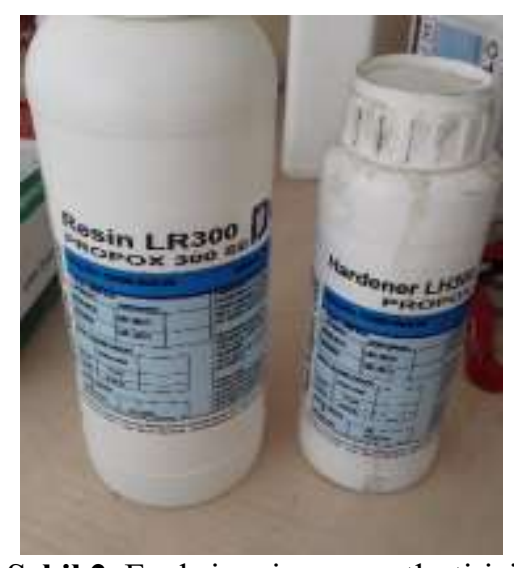

Şekil 2. Epoksi reçine ve sertleştirici

Kompozit numuneleri üretmek için hazırlanan yumurta kabuğu tozu ile epoksi+sertleştirici seti karışımına sabit oranlarda eklenip homojen bir yapı oluşması için tahta bir karıştırıcı yardımıyla karıştırıldı. Daha sonra karışım silikon kalıba dökülerek oda sıcaklığında 5 saat süre ile katılaşması (kürleşme) için bekletildi.

\subsection{Numuneler İçin Silikon Kalıp Hazırlama}

ASTM-D638 ve ASTM-D790 standartlarına uygun olarak üretilecek numuneler için RTV 2 kalıp oluşturma silikonu kullanıldı. Yumuşak ve esnek olması, içerisinde bulunan numuneyi çıkarmaya kolaylık ve tekrar kullanmaya olanak sağladığı için tercih edildi. Ayrıca pürüzsüz yüzeyler ve yumuşak olmasından kaynaklı kullanım kolaylığı sağladığından dolayı bu kalıplama yöntemi tercih edildi. Çekme ve üç nokta eğilme testleri için oluşturulan modeller, 170x20x30 mm boyutlarında bir kaba sabitlendi. Silikonun modellere yapışmasını engellemek için yüzeylerine silikon ayırıcı sprey sürülmüştür. Daha sonra sıvı halde bulunan RTV 2 kalıp silikonuna katalizör eklenerek iyice karıştırılıp, kapta bulunan modellerin üzerine döküldü. Reçine/yumurta kabuğu karışımının kalıp içerisine dökülmesi esnasında numunede oluşabilecek hava boşluklarını önlemek için iki taraftan yolluk açıklığı kalıplarda oluşturuldu. Hazırlanan silikon kalıplar Şekil 3'te gösterilmiştir.

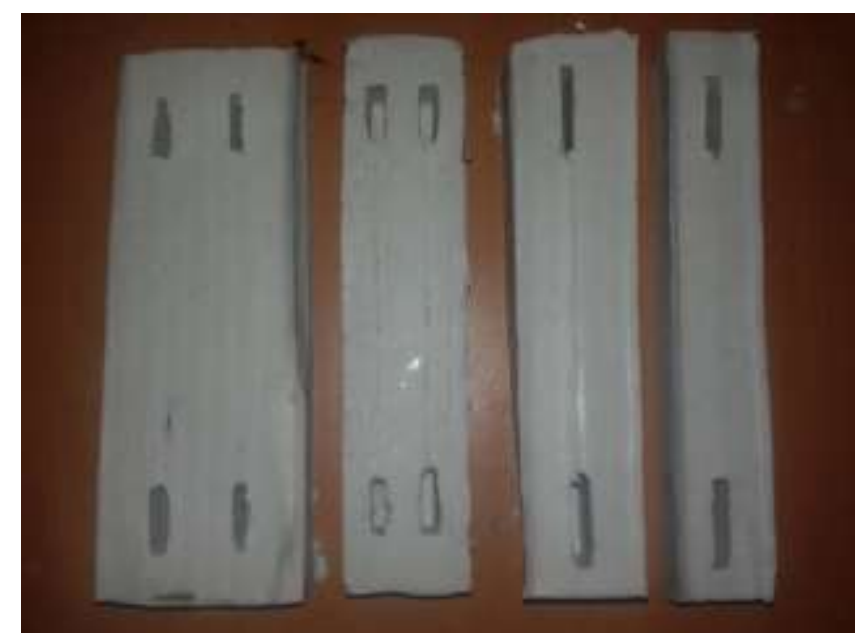

Şekil 3. RTV 2 silikon kalıpları 


\subsection{Kompozit Numunelerin Hazırlanması}

Epoksi ile sertleştirici oranı bütün numuneler için sabit tutularak ağırlıça belirlenen $\% 5, \% 10, \% 20$, $\% 30$ ve $\% 40$ oranlarında ve $106 \mu \mathrm{m}, 75 \mu \mathrm{m}, 63 \mu \mathrm{m}$ parçacık boyutlarında yumurta kabuğu tozu eklenmiş karışımlar oluşturulmuştur. Saf reçine ile üretilen, çekme testlerinde kullanılacak olan, köpek kemiği şeklindeki numunenin ağırlığı 14.4 gram ve üç nokta eğilme için dikdörtgen numunelerin ağırlığı ise 21.5 gram olarak ölçüldü. Bu numunelerin ağırlıklarının $\% 5, \% 10, \% 20, \% 30$ ve $\% 40$ kadar yumurta kabuk tozu kullanılarak çekme ve üç nokta eğilme testlerinde kullanılan birer adet numunenin, ağırlıkça yüzdesine bağlı yumurta kabuğu tozu ilavesinin gramajları Tablo 2'de verilmiştir.

Tablo 2. Her bir numune için gerekli olan yumurta kabuğu tozu miktarları

\begin{tabular}{|c|c|c|}
\hline Oranlar Testler & Çekme test numunesi & Üç nokta eğilme test numunesi \\
\hline$\% 0$ & - & - \\
\hline$\% 5$ & $0.72 \mathrm{gr}$ & $1.07 \mathrm{gr}$ \\
\hline$\% 10$ & $1.44 \mathrm{gr}$ & $2.15 \mathrm{gr}$ \\
\hline$\% 20$ & $2.88 \mathrm{gr}$ & $4.30 \mathrm{gr}$ \\
\hline$\% 30$ & $4.32 \mathrm{gr}$ & $6.45 \mathrm{gr}$ \\
\hline \multirow[t]{2}{*}{$\% 40$} & $5.76 \mathrm{gr}$ & $8.60 \mathrm{gr}$ \\
\hline & Toplam = 15.12 gr & Toplam $=22.57 \mathrm{gr}$ \\
\hline
\end{tabular}

İlk olarak $106 \mu \mathrm{m}$ parçacık boyutlu yumurta kabuğu tozu kullanılarak matris malzemesine ağırlıç̧a $\% 5, \% 10, \% 20, \% 30$ ve $\% 40$ oranlarında yumurta kabuğu tozu ilave edilmiş karışımlar oluşturulmuştur. Oluşturulan bu karışımın, homojen bir karışım olması için ortalama 6 dakika boyunca tahta kaşık yardımıyla karıştııılmıştır. Karışımda oluşan hava kabarcıklarını, en aza indirgemek için 5 dakika bekletilmiştir. RTV 2 silikon kalıpların içine, elde edilen karışımın yapışmasını engellemek ve rahat bir şekilde numunenin çıkarttırılması için kalıp ayırıcı sprey sürülmüştür. Daha sonra hava kabarcıklarını azaltmak için dinlenmeye bırakılan karışım, RTV 2 silikon kalıplara dökülmüştür. Karışımın küllenmesi için 6-8 saat bekletilmiştir ve daha sonra kalıplardan çıkartılan numunelerin sertleşmesi için en az 72 saat bekletilmiştir.

Şekil 4'te $106 \mu \mathrm{m}$ parçacık boyutundaki, yumurta kabuğu tozu ilave edilmiş ve saf epoksi ile hazırlanmış kompozit numunelerin bazıları verilmiştir. Diğer parçacık boyutları için aynı işlemler tekrarlanmıştır. Daha sağlıklı değerler elde etmek için çekme ve üç nokta eğilme testlerinde kullanmak üzere üçer adet numune üretilmiştir.

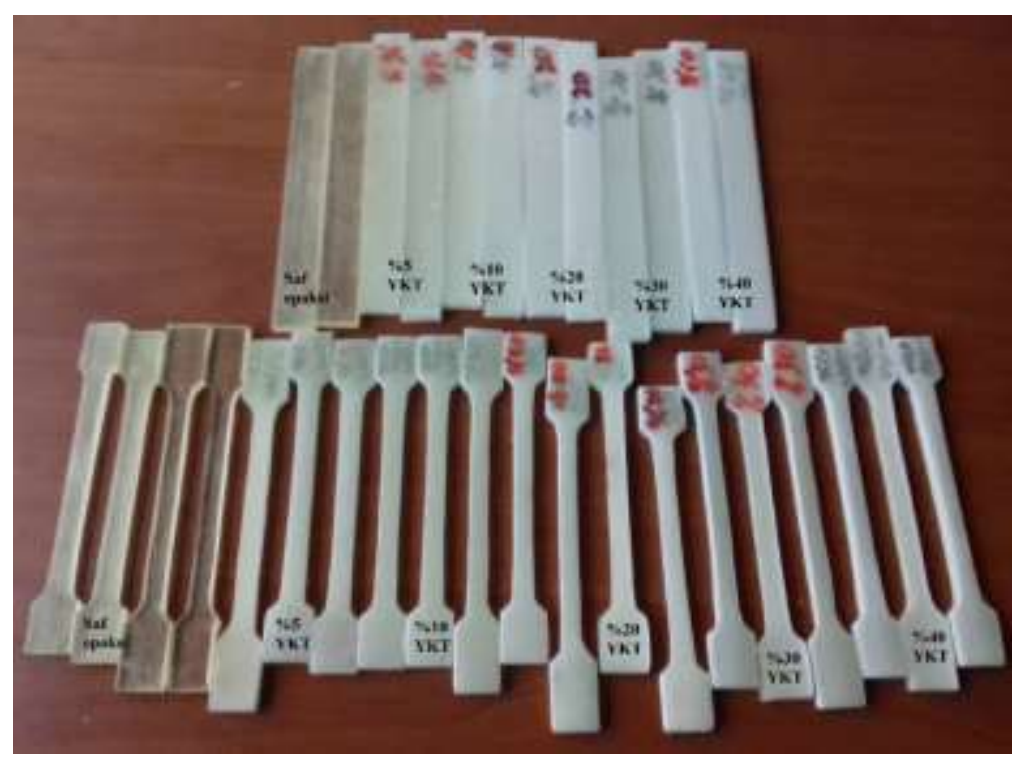

Şekil 4. Çekme ve üç nokta eğilme testleri için üretilen bazı numuneler 


\subsection{Deneysel Prosedür}

Epoksi reçineye $106 \mu \mathrm{m}, 75 \mu \mathrm{m}, 63 \mu \mathrm{m}$ parçacık boyutunda, yumurta kabuğu tozu ağırlıkça $\% 0, \% 5, \% 10$, $\% 20, \% 30$ ve $\% 40$ oranlarında eklenerek kompozit test numuneleri üretilmiştir. Üretilen numuneler üç nokta eğilme ve çekme testlerine maruz bırakılarak mekanik özellikleri incelendi. Daha sağlıklı sonuçlar elde etmek adına her bir parametreye ait üçer adet numune üretilip test edildi. Test edilen her üç numunenin ortalama değerleri hesaplandı. Maksimum çekme kuvveti, çekme gerilmesi değerleri, eğilme kuvveti ve eğilme gerilmesi değerleri belirlendi.

\subsection{1. Çekme Testi}

Çekme testleri, ASTM-D638 standardına göre gerçekleştirilmiştir. En yaygın kullanılan köpek kemiğine benzer numunelerinin boyutu ve geometrisi Şekil 5 'te verilmiştir. RTV 2 silikon kalıplara dökümle elde edilen numunenin uzunluğu (L) $150 \mathrm{~mm}$, kalınlığ 1 (t) ise $6 \mathrm{~mm}$ olarak ölçüldü. Üretilen numunelerin bazıları Şekil 4'te verilmiştir.

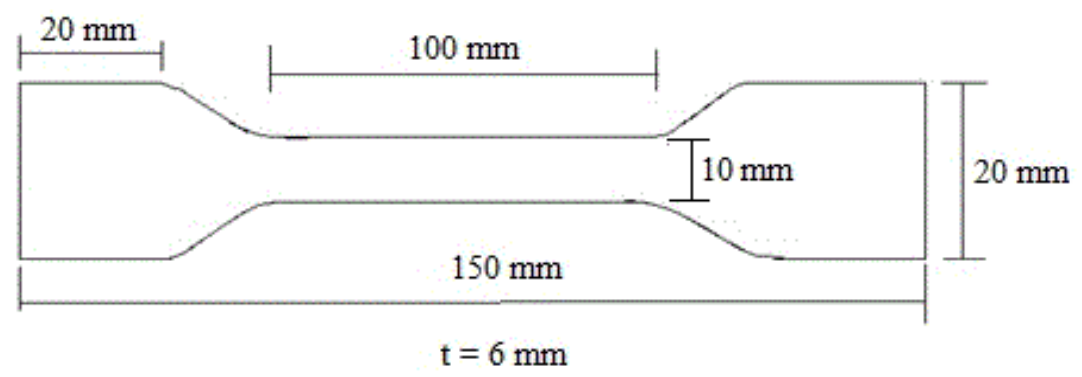

Şekil 5. Çekme test numunesinin geometrisi

Üretimi gerçekleştirilen numunelerin çekme testleri, Şekil 6'da gösterilen $5 \mathrm{kN}$ yük hücreli Shimadzu Marka Üniversal Çekme Test Cihazı kullanılarak $0.5 \mathrm{~mm} /$ dak. cihaz çene hızında oda sıcaklığında gerçekleştirilmiştir.

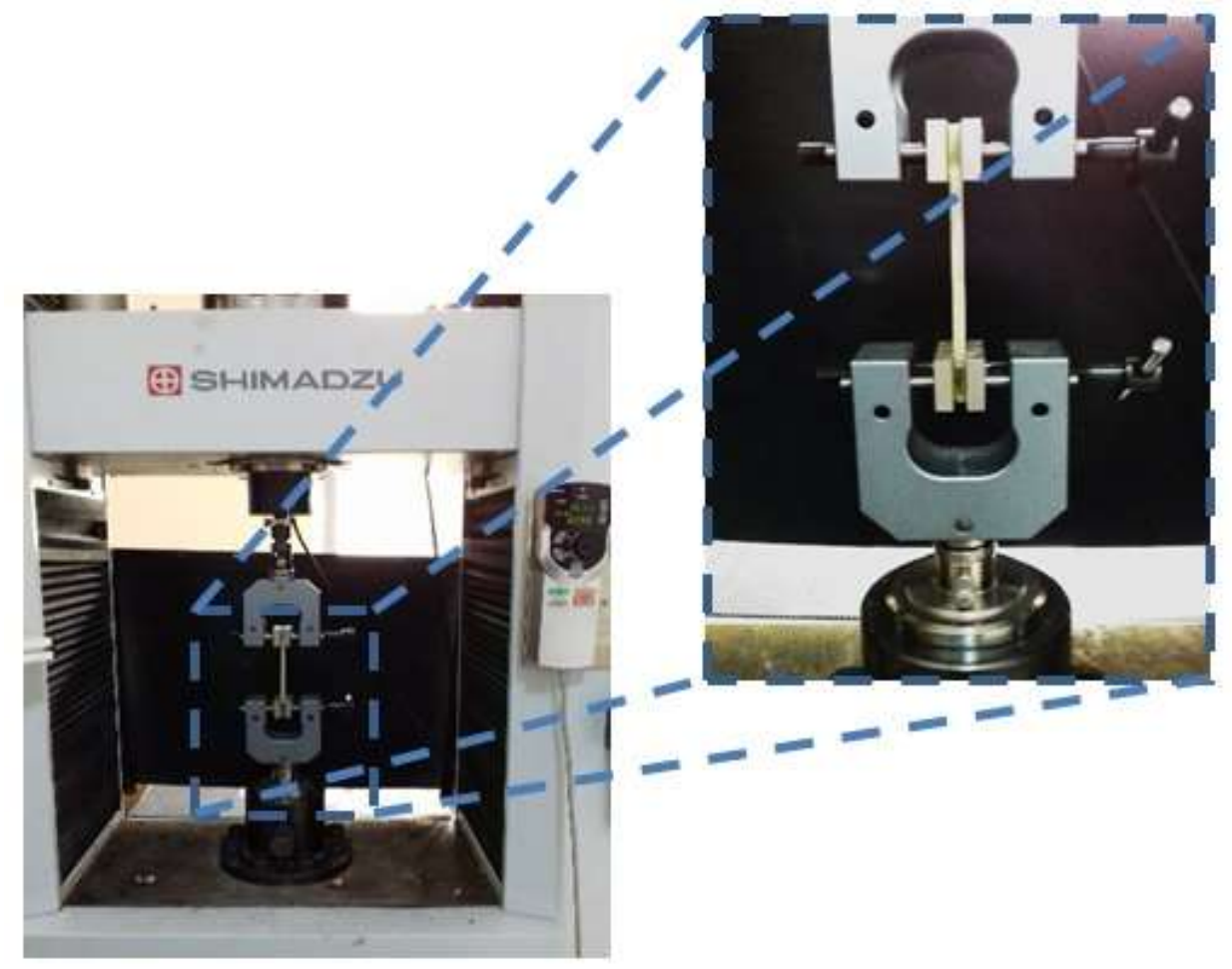

Şekil 6. Üniversal çekme cihazı ve numune 
Çekme testleri sonrasında numunelerin gerilme $\left(\sigma_{\text {çekme }}\right)$ değerleri denklem 1 kullanılarak hesaplanmıştır.

$$
\sigma_{\text {çekme }}=\frac{F}{A}
$$

$F$ maksimum kuvvet ve $A$ kesit alanıdır.

\subsection{2. Üç Nokta Eğilme Testi}

Üç nokta eğilme testleri, ASTM-D790 standardına uygun olarak Shimadzu marka üniversal test cihazında gerçekleştirildi. Üç nokta eğilme testi için 150x20x6 mm boyutlarında, saf reçine (epoksi+sertleştirici) ve farklı oranlarda yumurta kabuğu tozu ile reçine karışımdan elde edilen kompozit numunelerin bazıları Şekil 4'te verilmiştir.

Eğilme testleri, $0.5 \mathrm{~mm} /$ dak. cihaz çene hızında gerçekleştirildi (Şekil 7). Üç nokta eğilme testlerini gerçekleştirmek için test aparatının iki destek arası açıklığ $100 \mathrm{~mm}$ olarak ayarlandı. Daha sonra test numunesi iki destek üzerine ortalanarak yerleştirildi. Alt çeneye yerleştirilen dikdörtgen numuneye ortasından eğilme kuvveti uygulandı. Uygulanan kuvvetin etkisi altında numunede eğilme meydana gelmiştir. Eğilmeye başlayan kompozit numune, maksimum eğilme değerine ulaştığında kopma gerçekleşmiştir. Her bir test parametresi için üç numune üretilip test edildi. Test edilen üç numunenin maksimum eğilme kuvvetlerin ortalaması hesaplandi.

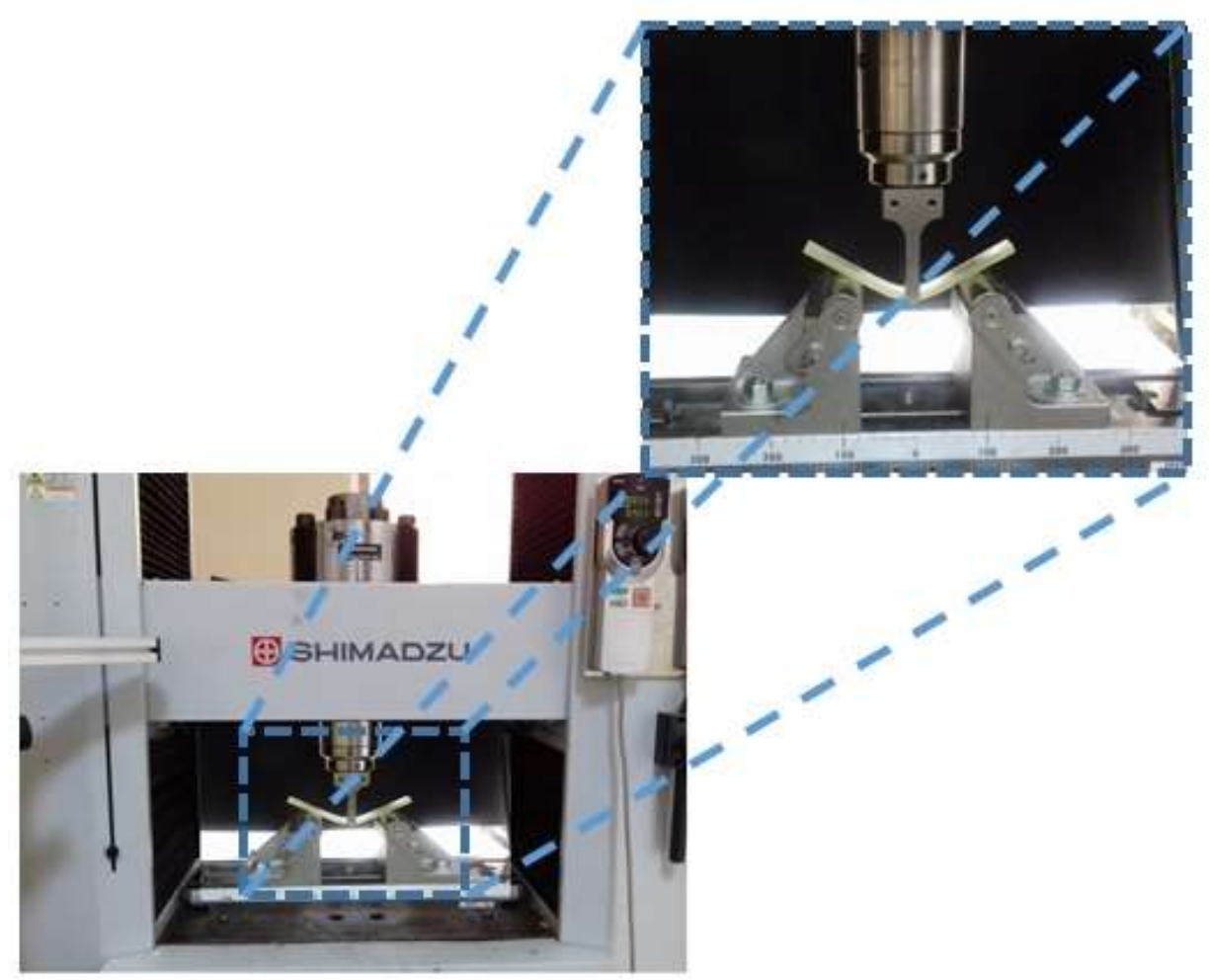

Şekil 7. Üniversal üç nokta eğilme aparatı ve test numunesi

Üç nokta eğilme testlerinde eğilme gerilme $\left(\sigma_{\text {eğilme}}\right)$ değerleri denklem 2 kullanılarak bulunmuştur.

$$
\sigma_{e \breve{\mathrm{g}} i l m e}=\frac{3 F L}{2 b t^{2}}
$$

Bu denklemde $F$ maksimum kuvvet, $L$ alt destekler arasındaki mesafe, $b$ numune genişliği, $t$ ise kalınlığıdır. 


\section{Bulgular ve Tartışma}

Bu çalışmada, epoksi reçineye ağırlıkça $\% 0, \% 5, \% 10, \% 20, \% 30, \% 40$ oranlarında $106 \mu \mathrm{m}, 75 \mu \mathrm{m}$ ve $63 \mu \mathrm{m}$ parçacık boyutunda yumurta kabuğu tozu takviyeli kompozit numuneler üretilip, test edilmiştir. İlk olarak, sade (\%0 katkı oranı) reçine numunelerin testleri daha sonra diğer numunelerin testleri gerçekleştirilmiştir. Burada parçacık takviyeli polimer esaslı numunelerin mekanik davranışını incelemek için çekme ve üç nokta eğilme testleri yapılmıştır. Böylece iki farklı uygulaması olan test yöntemleri ile numunelerin davranışları belirlenmeye çalışılmıştır.

\section{1. Çekme Testleri}

Sağlıklı sonuçlar elde etmek için her bir parametreye bağlı deney setinde kullanılmak üzere üç numune üretildi. Testlere tabi tutulan kabuk tozu takviyeli kompozit numuneler, kopma işlemi gerçekleşene kadar yüklemeye maruz bırakıldı. Her bir parametreye bağlı üretilen numunelerin test sonucu elde edilen maksimum çekme kuvvet ve gerilmeleri belirlendi.

\subsubsection{Yumurta Kabuğu Tozunun (YKT) Ăğılık Oranlarının İncelenmesi}

Reçineye $106 \mu \mathrm{m}, 75 \mu \mathrm{m}$ ve $63 \mu \mathrm{m}$ parçacık boyutlarındaki yumurta kabuğu tozunun $\% 0, \% 5, \% 10, \% 20$, $\% 30$ ve \%40 ağırlık oranlarında eklenmesi ile hazırlanan numuneler çekme testlerine maruz bırakılarak sabit parçacık boyutunda ilave edilen kabuk tozunun yüzde ağırlık etkisi incelenmiştir. Örnek olarak $106 \mu \mathrm{m}$ parçacık takviyeli numunelerin çekme kuvveti-uzama eğrileri Şekil 8' de verilmiştir. Eğriler incelendiğinde, ağırlıkça $\% 5$ oranı ile yumurta kabuğu tozu ilave edilerek hazırlanan kompozit numunelerde maksimum kuvvet ve gerilme değerleri tespit edilmiştir. En düşük değerler ise \%40 ağırlık oranı ile üretilen numuneler için elde edilmiştir.

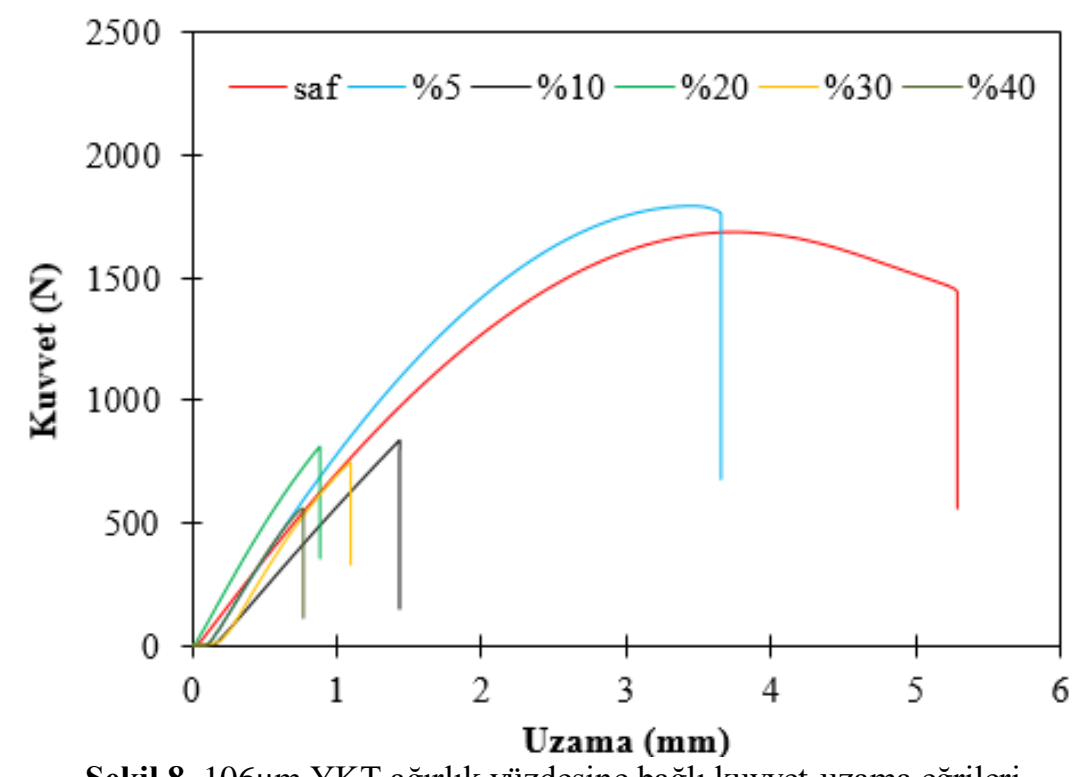

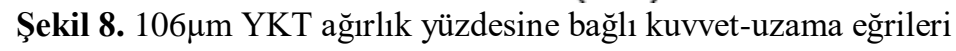

Elde edilen test sonuçlarının daha iyi yorumlanabilmesi için Şekil 9 ve Şekil 10'da verilen grafikler oluşturulmuştur. Ağırlık yüzdesine bağlı ilave edilen kabuk tozu oranı \%0'dan \%5'e artırılırken, çekme gerilmesi değerlerinde artış görülmektedir. Ancak yumurta kabuğu tozu oranı $\% 5$ 'ten \%40'a doğru artırıldığında çekme gerilmesi değerlerinde kademeli olarak düşüşler olmuştur. Benzer sonuçlar Nawang ve ark. [4] tarafından yapılan çalışmada takviye elamanı olarak kullanılan artan nişasta oranında mekanik özelliklerin düştügü görülmüştür. Ayrıca Ateş ve Tok [15], takviye elemanlarının ağırlıkça yüzde oranında eklenmesiyle çekme ve akma gerilmesinin belirli bir orana kadar arttığını ve daha sonra azaldığı belirlenmiştir. Benzer sonuçlar Shuhadah ve Supri [17] çalışmasında da elde edilmiş̧tir. Yumurta kabuğu tozunun ağırlık yüzdesine bağlı çekme gerilme değerlerindeki değişim Şekil 9'da sunulmuştur. 


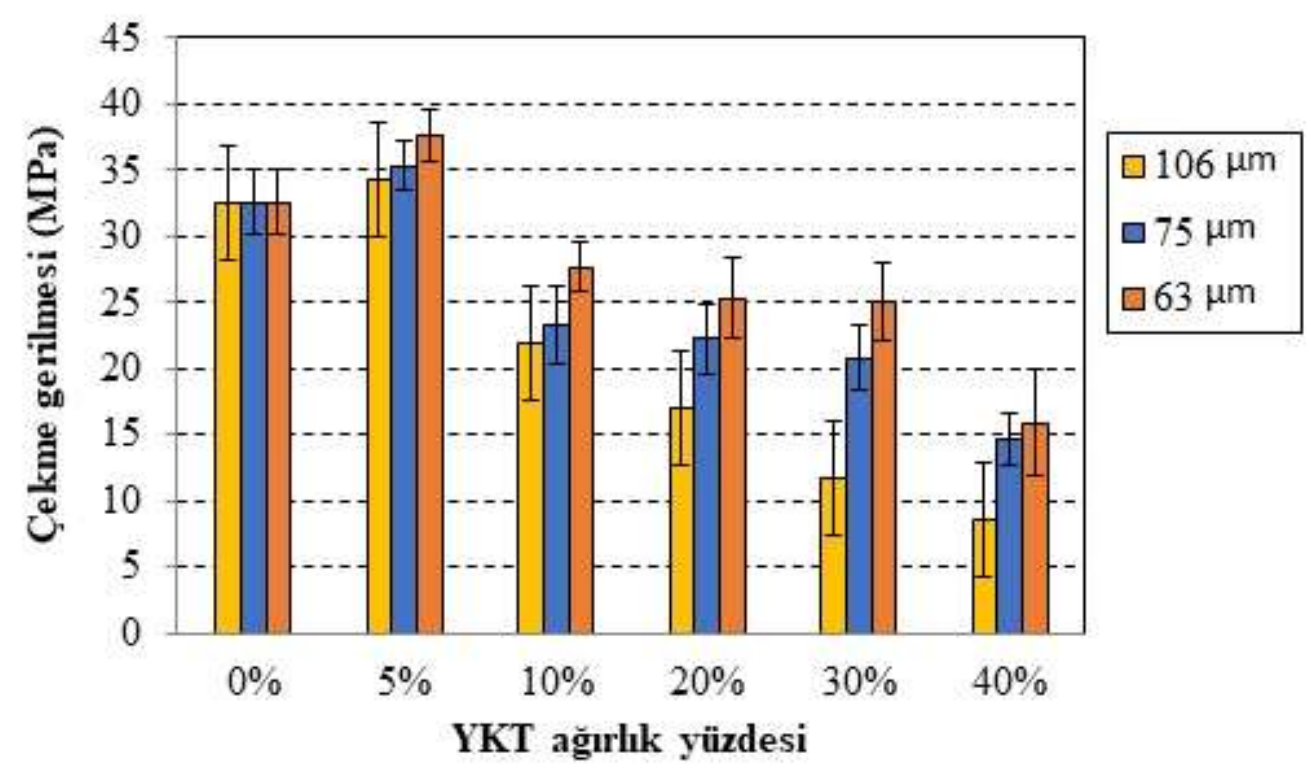

Şekil 9. YKT ağırlık yüzdesine bağlı çekme gerilme değerleri

İlave edilen YKT oranı \%5'ten fazla eklendiğinde kompozit numunelerde gevrek bir yap1 oluşmasına neden olmuştur. Bundan dolayı saf epoksi ile üretilip test edilen numunelerin çekme gerilme değerlerinden daha düşük çekme gerilme değerleri gözlemlenmiştir. Maksimum çekme kuvvetlerindeki bu değişim, epoksi ile yumurta kabuk tozunu bir arada tutan bağlayıcı kuvvetin, artan yumurta kabuk tozu ile zayıf kalmasından kaynaklanmaktadır. Hazırlanan $75 \mu \mathrm{m}$ parçacık boyutundaki YKT takviyeli kompozit numunelerin çekme test sonuçlarında maksimum çekme kuvveti ve gerilme değeri, YKT \%5 ağırlık takviyesi oranında ve maksimum çekme kuvveti $1905 \mathrm{~N}$, maksimum çekme gerilme değeri 37.35 MPa elde edildi. $63 \mu \mathrm{m}$ yumurta kabuğu tozunun ağırlık yüzdesine bağlı çekme gerilme değerlerindeki değişimi yorumlandığında, maksimum çekme kuvveti $1918.36 \mathrm{~N}$, maksimum çekme gerilme değeri 37.61 MPa olarak, yumurta kabuk tozunun $63 \mu \mathrm{m}$ boyutunda ve $\% 5$ ağırlık takviyesinde elde edildi.

Epoksi reçineye $106 \mu \mathrm{m}, 75 \mu \mathrm{m}$ ve $63 \mu \mathrm{m}$ parçacık boyutlarındaki YKT takviyesinin ağırlık oranlarının etkisi incelendi. Yapılan çekme test sonuçlarına göre, üç farklı parçacık boyutundaki numunelerin maksimum çekme kuvveti ve gerilme değerleri, YKT \%5 ağırlık oranında ilavesinde elde edilmiştir. Epoksi reçineye $100 \mu \mathrm{m}$ parçacık boyutuna sahip yumurta kabuğunun ağırlıkça \%5 eklenmesi ile maksimum çekme dayanım değerleri elde edilmiştir[19]. Shin ve ark. [21], yumurta kabuğunun 100 $\mu \mathrm{m}$ parçacık boyutunda \%10 ağırlık oranında kullanımı ile numunelerin çekme dayanımında \%18 iyileştirme yaptığını gözlemlemiştir. Benzer sonuçlar Golakiya [22] tarafından da bulunmuştur. Daha küçük partiküllerin daha geniş spesifik yüzey alanlarından dolayı polimer zincirleriyle maksimum ara yüzey temasına sahip olduğu ve böylece daha yüksek mekanik özellikler gösterebilmektedir.

\subsubsection{Yumurta Kabuğu Tozunun Parçacık Boyutunun İncelenmesi}

Kompozit numunelerin maksimum çekme gerilme değerlerini, daha önce yumurta kabuk tozunun \%5 ağırlık oranında ilavesinde elde edilmişti. Burada yumurta kabuk tozunun ağırlık yüzdesi sabit tutularak, mikron metre seviyesindeki boyutları incelenmiştir. Epoksi reçineye, ağırlıkça \%5 oranında $106 \mu \mathrm{m}$, $75 \mu \mathrm{m}$ ve $63 \mu \mathrm{m}$ parçacık boyutlarındaki yumurta kabuğu tozu eklenen numuneler karşılaştırılmıştır.

Yapılan çekme testlerinde maksimum gerilme değerleri, yumurta kabuğu tozunun, \%5 ağırlık ilavesi ve $63 \mu \mathrm{m}$ boyuta sahip olan numunelerde elde edildiği Şekil 10'da gösterilmiştir. Ayrıca kabuk tozunun boyutu küçüldükçe gerilme değerlerinin kademeli olarak artış gösterdiği görülmüştür. Tüm kabuk tozu boyutlarında $\% 5$ ağırlık oranında üretilen numunelerin testi sonrasında elde edilen gerilme değerlerinin saf epoksi reçine kullanılarak üretilen numunelerin test sonuçlarından daha yüksek elde edildiği görülmüştür. Ağırlıkça \%5 yumurta kabuğunun epoksi reçine içerisinde iyi bir şekilde dağılması ve daha iyi bir bağlanma sağlaması nedeniyle gerilme mukavemetinde iyileşme meydana getirmiştir. Parçacık boyutu $100 \mu \mathrm{m}$ olan kabuğun ağırlıcça \%5 ile takviyelendirilmesi ile hazırlanan numunelerin 
daha yüksek çekme gerilme değerleri Hameed ve Jassim [19] tarafından yapılan çalışmada da tespit edilmiştir. Yumurta kabuk oranı ağırlıkça \%10'dan \%25'e artırılması ile çekme gerilme değerleri düşmüştür. Yumurta kabuğunun $\% 10$ ağırlık oranında kullanımı ile numunelerin çekme gerilme değerleri \%18 artmıştır [21].

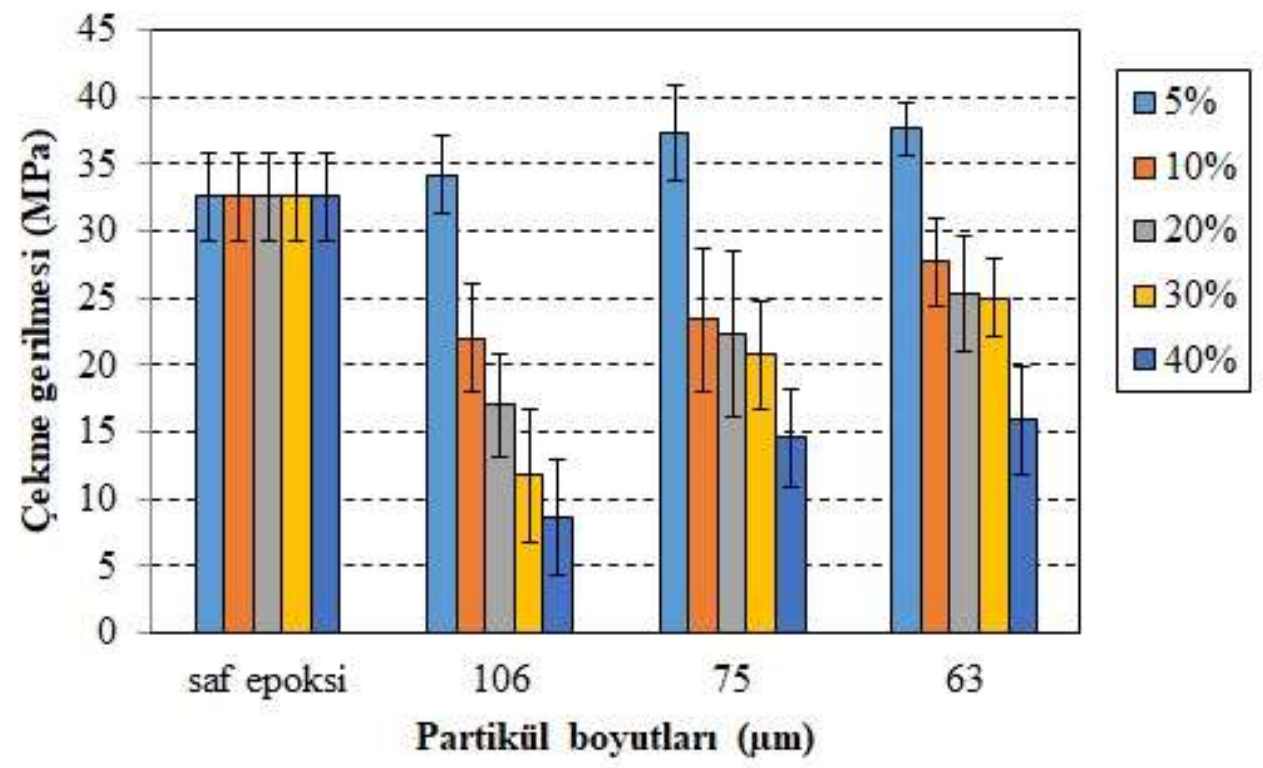

Şekil 10. YKT boyutuna bağlı çekme gerilme değerleri

Yumurta kabuğu tozu takviyeli kompozit numunelerde, parçacık boyutunun küçülmesi, epoksi reçine ile yumurta kabuk tozu arasında daha iyi bir ara yüz oluşturmasına ve kavramasına olanak sağlamıştır. Tüm yumurta kabuk tozu boyutları kullanılarak üretilen numunelerin testi sonrasında elde edilen çekme gerilme değerlerinin, saf epoksi reçine kullanılarak üretilen numunelerin test sonuçlarından daha yüksek elde edildiği görülmüştür. Farklı ağırlık yüzdelerinde YKT ile güçlendirilmiş kompozit numunelerin tümünde, yumurta kabuk tozunun parçacık boyutu küçüldükçe çekme gerilme değerlerinde artış olduğu gözlemlenmiştir. Shin ve ark. [21] tarafından yapılan çalışmada $100 \mu \mathrm{m}$ ve $150 \mu \mathrm{m}$ parçacık boyutlarının çekme gerilmelerine etkisi incelendiğinde, $100 \mu \mathrm{m}$ boyutunda daha yüksek gerilme değerleri tespit edilmiştir. Bunun sebebi daha küçük partikül boyutların maksimum yüzey alanlarının reçine polimer tarafından daha iyi ara yüzey teması sağlamasından kaynaklandığı düşünülmektedir.

\section{2. Üç Nokta Eğilme Testi}

Eğilme gerilmelerini hesaplamak için ASTM-D790 standardına uygun üretilen numuneler üç nokta eğilme testlerine tabi tutulup, maksimum kuvvet değerleri elde edildi. Öncelikle yumurta kabuk tozunun parçacık boyutu sabit tutularak, kompozit numuneye yumurta kabuk tozunun ağırlıkça yüzde ilavesi etkisi incelendi. Daha sonra maksimum eğilme gerilmesinin elde edildiği YKT takviye yüzdesi sabit tutularak, eklenen YKT boyutu etkisi incelendi.

\subsubsection{Yumurta Kabuğu Tozunun Ağırlık Oranının İncelenmesi}

Testlere tabi tutulan kompozit numunelerin, takviye edilen yumurta kabuk tozunun boyutu sabit tutuldu. Kompozit numuneye ilave edilen yumurta kabuk tozunun ağırlık yüzdesi araştırıldı. Saf epoksi ile üretilen numunelerin test sonuçlarıyla karşılaştırıldı. Epoksi reçineye, $106 \mu \mathrm{m}$ boyutundaki yumurta kabuğu tozu ağırlıkça $\% 0, \% 5, \% 10, \% 20, \% 30$ ve $\% 40$ oranlarında ilave edilerek üç nokta eğilme testlerine ait kuvvet-uzama eğrileri Şekil 11 'de verilmiştir. 


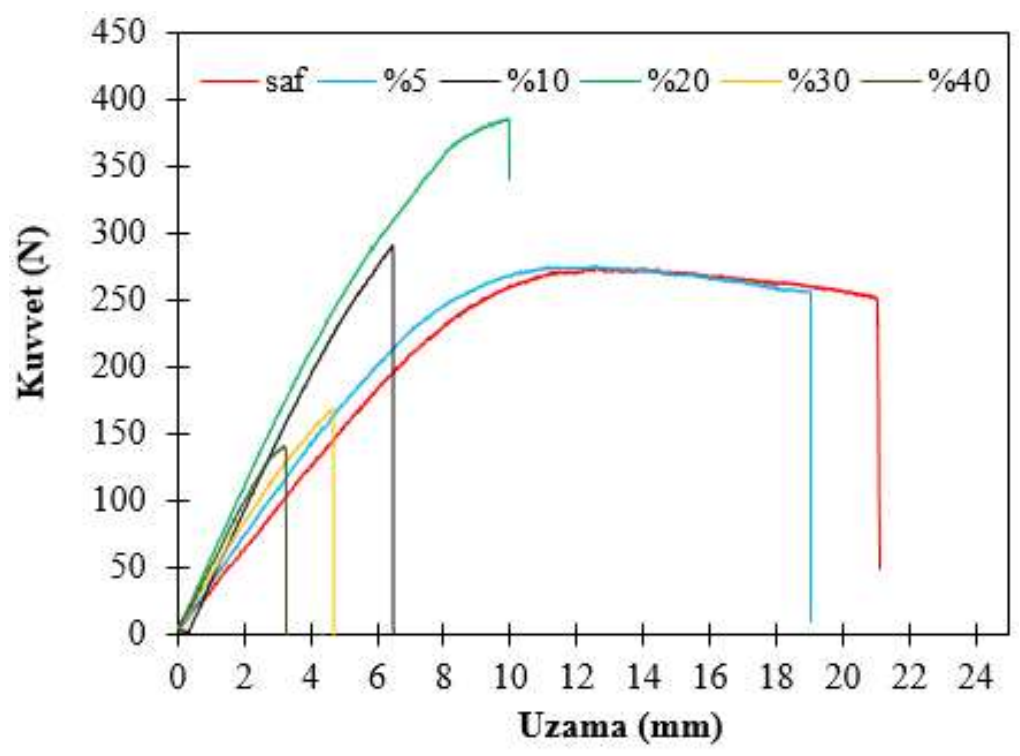

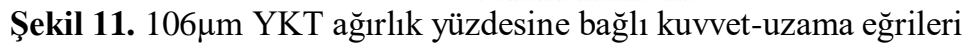

Testler sonucunda, maksimum eğilme kuvveti ve eğilme dayanımı, ağırlıkça \%20 oranında yumurta kabuğu tozu takviyeli kompozit numunelerde elde edilmiştir. Shashir ve ark. [14] çalışmalarında, yumurta kabuğunun \%20 oranında epoksi reçineye ilavesinde üretilen numunelerde maksimum eğilme dayanımı ve sertliği elde etmişlerdir. Yumurta kabuğu tozunun numune üretiminde ağırlıkça kullanımı eğilme dayanımını artırdığı görülmüş̧ür. Fakat kabuk tozunun $\% 30$ ve $\% 40$ ağırlık oranlarında kullanımı durumunda numunelerin eğilme dayanımında azalma tespit edilmiştir. Şekil 12'de görüldüğü gibi kabuk tozunun kullanımı belli bir orana (\%20) kadar kompozit numunelerin eğilme dayanımını artırdığını söyleyebiliriz. En düşük kuvvet değeri \%40 oranı için elde edilmiştir. Adeosun ve ark. [5] farklı oranlarda kalsiyum karbonat dolgu parçacıkları ilave ederek ürettikleri polietilen esaslı kompozit numunelerde kalsiyum karbonat yüzdesinin artırılmasıyla eğilme gerilmesinin de arttığını tespit etmişlerdir. Şekil 12 incelendiğinde, kompozit numuneye $63 \mu \mathrm{m}$ boyutunda ve $\% 20$ ağırlık oranında YKT takviyesinde, maksimum eğilme gerilme dayanımı $68.60 \mathrm{MPa}$ ve en düşük eğilme gerilme dayanımı ise $\% 40$ takviyesinde $46.15 \mathrm{MPa}$ olarak elde edildi. Kompozit numuneye $75 \mu \mathrm{m}$ boyutunda ve \%20 ağırlık oranında YKT takviyesinde, maksimum eğilme gerilmesi $66.70 \mathrm{MPa}$ ve en düşük eğilme gerilmesi ise $\% 40$ takviyesinde $33.57 \mathrm{MPa}$ olarak elde edildi. $106 \mu \mathrm{m}$ boyutu ve $\% 20$ ağırlık oranında YKT takviyesinde, maksimum eğilme gerilmesi $63.54 \mathrm{MPa}$ ve en düşük eğilme gerilmesi ise $\% 40$ takviyesinde $32.45 \mathrm{MPa}$ 'ır. Polimer matrise eklenen yumurta kabuğun ağırlık oranının $\% 5$ 'ten $\% 15$ 'e artırılması ile eğilme gerilme değerlerinin arttığ ve $\% 15$ 'ten daha fazla eklenmesi ile düştüğü görülmüştür [19].

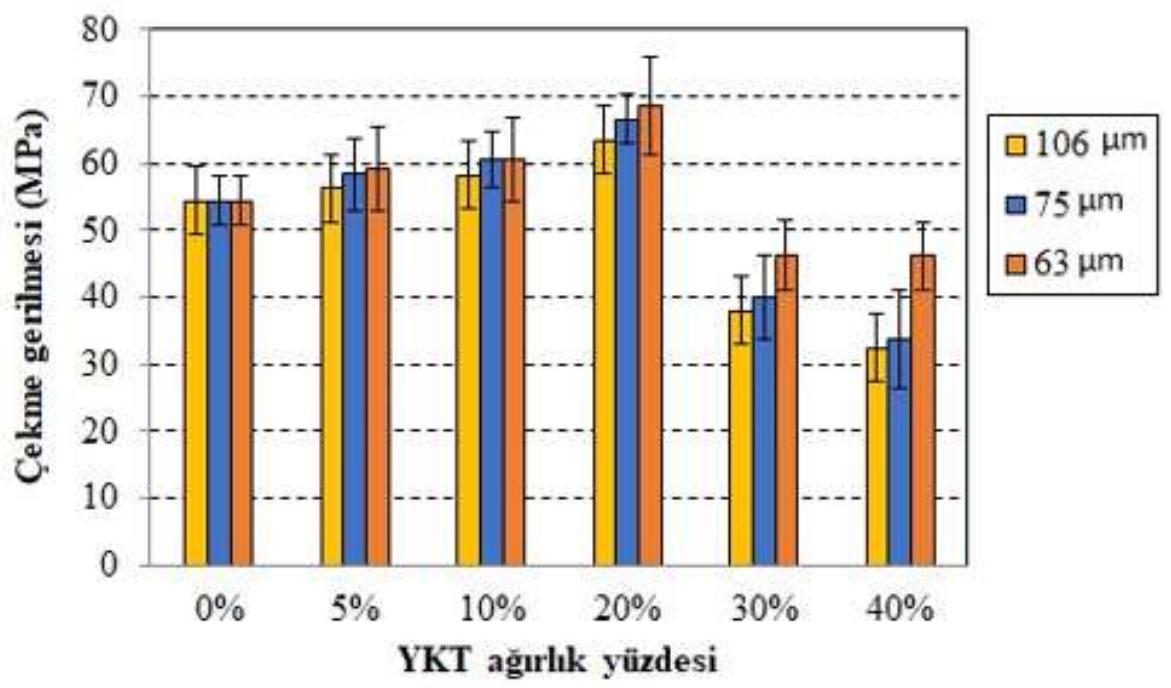

Şekil 12. YKT ağırlık yüzdesine bağlı eğilme gerilme değerleri 


\subsubsection{Yumurta Kabuğu Tozunun Parçacık Boyutunun İncelenmesi}

Kompozit numunelerin maksimum eğilme değerlerini, yumurta kabuk tozunun \%20 ağırlık oranında ilavesinde elde edilmişti. Burada yumurta kabuk tozunun takviye yüzdesi oranı sabit tutularak, mikron metre seviyesindeki boyutları incelenmiştir. Kompozit numuneye ilave edilen YKT parçacık boyutunun küçülmesiyle, maksimum eğilme değerlerindeki değişim Şekil 13 'te verilmiştir. Kompozit numunelerin maksimum eğilme kuvveti ve eğilme gerilme değeri, $63 \mu \mathrm{m}$ boyutundaki yumurta kabuk tozu takviyeli numunelerde elde edildi. Maksimum eğilme kuvveti $329.30 \mathrm{~N}$ ve eğilme gerilme değeri $68.60 \mathrm{MPa}$ olarak ölçüldü. En düşük gerilme değeri ise $106 \mu \mathrm{m}$ boyutundaki kabuk tozunun $\% 40$ ağırlık oranında ilave edilmiş numunelerde elde edilmiştir.

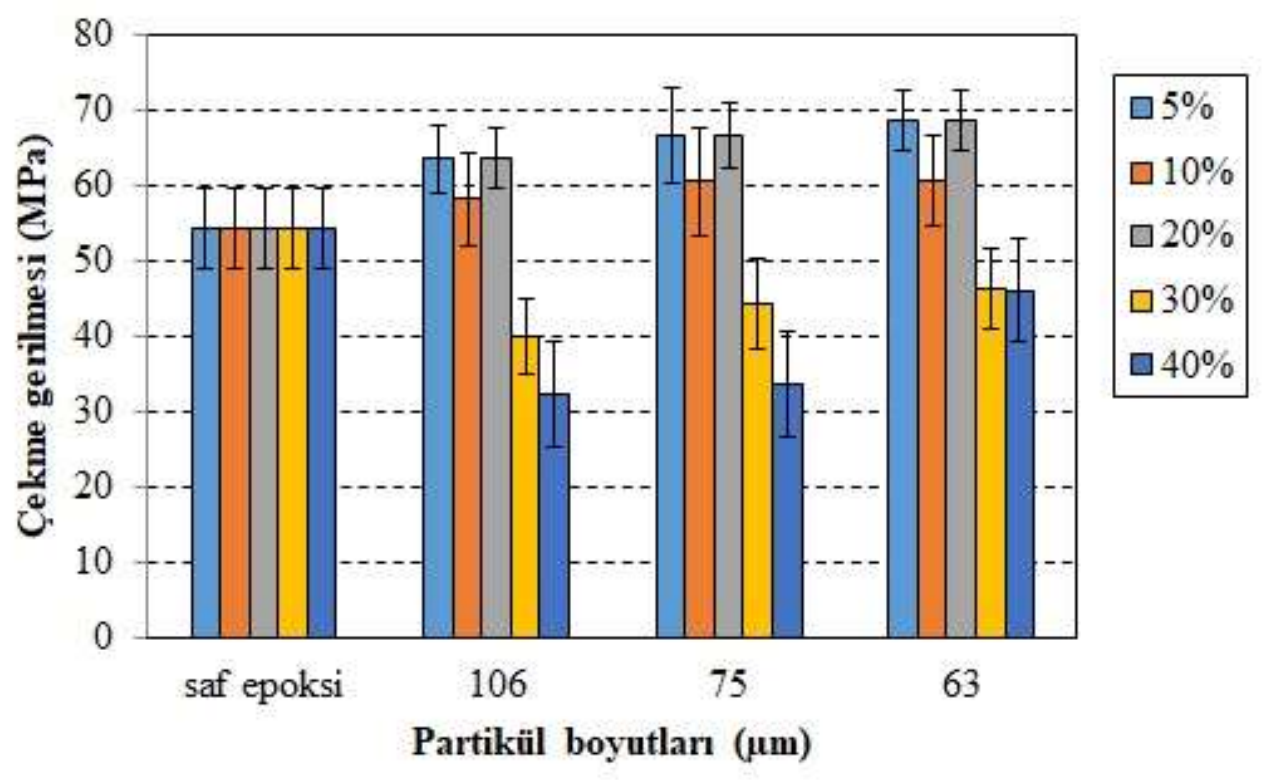

Şekil 13. YKT boyutuna bağl1 eğilme gerilme değerleri

Numunelere ilave edilen YKT parçacık boyutunun küçülmesiyle, epoksi ile yumurta kabuk tozu arasında daha iyi kavrama ve yapışma sağlanmıştır. Böylelikle daha iyi bir ara yüzey oluşturulmuştur. Buna bağlı olarak kompozit malzemede eğilme kuvveti ve eğilme gerilmesinde artışlar görülmüştür. Kompozit numuneye $\% 5$ ve $\% 20$ ağırlık oranında ve $63 \mu \mathrm{m}$ YKT takviyesinde maksimum eğilme gerilme dayanımı $68.60 \mathrm{MPa}$ olarak elde edildi. Kompozit numuneye $\% 10$ ağırlık oranında YKT takviyesinde maksimum eğilme gerilme dayanımı 60,68 MPa olarak elde edildi. Bütün YKT parçacık boyutları için, $\% 30$ ve $\% 40$ ağırlık oranında takviye edildiğinde, numunelerin dayanımında ciddi azalmalar meydana geldiği gözlemlenmiştir. Ve saf epoksi reçine ile üretilen numunelerin eğilme dayanımından çok daha düşük olduğu görülmektedir. Çünkü artan takviye oranındaki YKT epoksi esaslı numunelerin eğilme direncini düşürmüştür. Benzer sonuçlar Adal [9] tarafindan yapılan çalışmada, artan yumurta kabuğu tozu miktarı ile ekmeklerin sertlik değerinde düşüşe neden olduğu görülmüştür.

\section{Sonuçlar ve Öneriler}

Mevcut çalışma yumurta kabuğu tozu takviyeli epoksi esaslı kompozit malzemenin, geleneksel malzemelere oranla daha ekonomik ve imalat kolaylığ sağladığını ortaya koymuştur. Böylece yumurta kabuk atığının değerlendirilmesi için farklı bir alternatif sunmaktadır. Epoksi reçineye, yumurta kabuğu tozu ilave edilerek elde edilen kompozit numunelerin mekanik davranışı incelenmiş olup ve aşağıda verilen sonuçlar elde edilmiştir:

a) YKT ile güçlendirilmiş yeni bir epoksi esaslı kompozit malzeme başarılı bir şekilde üretilmiştir.

b) YKT takviye oranının artırılmasıyla kompozit malzemenin eğilme ve çekme mukavemetlerinin belirli bir orana kadar arttığı belirlenmiştir. 
c) Kompozit malzeme üretiminde kullanılan YKT oranın daha fazla artırılması, epoksi ile YKT bir arada tutan bağlayıcı kuvvetin zayıf kalmasına neden olmuştur. Buna bağlı olarak çekme ve eğilme mukavemetinin olumsuz etkilendiği görülmüştür.

d) Kompozit numunelerde maksimum eğilme mukavemeti, takviye edilmiş yumurta kabuk tozunun $\% 20$ ağırlık oranında oluştuğu gözlemlenmiştir.

e) Maksimum çekme mukavemeti ise yumurta kabuk tozunun $\% 5$ ağırlık oranında meydana gelmiştir.

f) Yumurta kabuğu boyutunun kompozitin mekanik davranışını etkilediği görülmüştür. En yüksek gerilme değerleri $63 \mu \mathrm{m}$ boyutlarında elde edilmiştir. Çünkü yumurta kabuk boyutu azaldıkça matris tarafından maksimum temas yüzey alanı oluşmaktadır. Böylece daha iyi matris ve takviye elemanı ara yüzey kuvveti gerçekleşmektedir.

\section{Yazarların Katkısı}

Bu çalışma, Doç. Dr. Mehmet Emin DENIZZ danışmanlığında Abdurrahim GÜNEŞ tarafından yapılan "Yumurta Kabuğu Takviyeli Polimer Esaslı Kompozitlerin Mekanik Davranışının İncelenmesi” başlıklı Yüksek Lisans Tez çalışmasından üretilmiştir.

\section{Çıkar Çatışması Beyanı}

Yazarlar arasında herhangi bir çıkar çatışması bulunmamaktadır.

\section{Araştırma ve Yayın Etiği Beyanı}

Yapılan çalışmada araştırma ve yayın etiğine uyulmuştur.

\section{Kaynaklar}

[1] Güneş A. 2019. Yumurta Kabuğu Takviyeli Polimer Esaslı Kompozitlerin Mekanik Davranışının İncelenmesi. Yüksek Lisans Tezi, Batman Üniversitesi, Fen Bilimleri Enstitüsü, Batman.

[2] Xanthos M. 2010. Polymers and Polymer Composites. Weinheim: Wiley-VCH, 4-16.

[3] Leong C. 2016. Development Polypropylene (PP)-Modified Chicken Eggshell Composites. Faculty of Engineering and Green Technology Universiti Tunku Abdul Rahman, 10-15.

[4] Nawang R., Danjaji I., Ishiaku U., Ismail H., Mohd Ishak Z. 2001. Mechanical properties of sago starch-filled linear low density polyethylene (LLDPE) composites. Polymer Testing, 20 (2): 167 172.

[5] Adeosun S., Usman M., Akpan E., Dibie W. 2014. Characterization of LDPE Reinforced with Calcium Carbonate Fly Ash Hybrid Filler. Journal of Minerals and Materials Characterization and Engineering, 2 (4): 334-345.

[6] He H., Li K., Wang J., Sun G., Li Y., Wang J. 2011. Study on thermal and mechanical properties of nano-calcium carbonate/epoxy composites. Materials Design, 32 (8-9): 4521-4527.

[7] Yoo S., Hsieh J., Zou P., Kokoszka J. 2009. Utilization of calcium carbonate particles from eggshell waste as coating pigments for ink-jet printing paper. Bioresource Technology, 100 (24): 6416-6421.

[8] Mohammadi M., Lahijani P., Mohamed A. 2014. Refractory dopant-incorporated CaO from waste eggshell as sustainable sorbent for $\mathrm{CO}_{2}$ capture: Experimental and kinetic studies. Chemical Engineering Journal, 243: 455-464.

[9] Adal S. 2018. Yumurta Kabuğu Tozu Kullanılarak Mineral Madde Bakımından Zenginleştirilen Ekmeklerin Bazı Fiziksel ve Kimyasal Özelliklerinin Belirlenmesi. Yüksek Lisans Tezi, Celal Bayar Üniversitesi, Fen Bilimleri Enstitüsü, Manisa.

[10] Kıllı U., Tutuş A., Çiçekler M., Özdemir F. 2017. Atık ofis kâğıtları ve yumurta kabuklarından yazı-tabı kâğıdı üretimi. Harran 1. Uluslararası Ar-Ge Proje Pazarı, Şanlıurfa.

[11] Wei H., Shen Q., Zhao Y., Zhou Y., Wang D., Xu, D. 2005. On the crystallization of calcium carbonate modulated by anionic surfactants. Journal of Crystal Growth, 279 (3-4): 439-446. 
[12] Chojnacka K. 2005. Biosorption of Cr(III) ions by eggshells. Journal of Hazardous Materials. 121 (1-3): 167-173.

[13] Özğan A.O. 2019. Plastik Kompozit Üretiminde Odun ve Yumurta Kabuğu Kullanımının Araştırılması. Yüksek Lisans Tezi, Kahramanmaraş Sütçü İmam Üniversitesi, Fen Bilimleri Enstitüsü, Kahramanmaraş.

[14] Shashir S.K., Apsarraj A.D., Shashidhar A.L., Basavaroodh A.B. 2017. Experimental investigation of mechanical properties of egg shell powder reinforced with epoxy. International Journal of Emerging Technologies and Innovative Research, 4 (7): 157-160.

[15] Tok A., Ateș S. 2017. Yumurta Kabuğu Tozu, $\mathrm{SiC}$ ve $\mathrm{Al}_{2} \mathrm{O}_{3}$ Takviyeli Al6061 matrisli hibrit kompozitlerin gerilme dayanımlarının incelenmesi. I. Uluslararası Türk Dünyası Mühendislik ve Fen Bilimleri Kongresi, Antalya.

[16] Gürlek G., Oğurol H., Erden S. 2015. Kapalı kalıpta üretilen poliüretan köpük malzemesine yumurta kabuğu tozu ilavesinin isı iletim katsayısına ve basma dayanımına etkisi. 3.Ege Kompozit Malzemeler Sempozyumu, İzmir.

[17] Shuhadah S., Supri A.G. 2009. LDPE-isophthalic acid-modified eggshell powder composites (LDPE/ESPI). Journal of Physical Science, 20 (1): 87-98.

[18] Panchal M., Raghavendra G., Rahul Reddy A., Omprakash M., Ojha S. 2020. Experimental investigation of mechanical and erosion behavior of eggshell nanoparticulate epoxy biocomposite. Polymers and Polymer Composites, 1-12.

[19] Hameed H.K., Jassim W.H. 2019. Improvement of some mechanical properties of epoxy using uncarbonized and carbonized eggshell powder. AIP Conference Proceedings, 2190, 020026, 1-8.

[20] Asha A., Sekhar V.C. 2014. Investigation on the mechanical properties of egg shell powder reinforced polymeric composites. International Journal of Engineering Research \& Technology (IJERT), 3 (12): 288-291.

[21] Shin L.J., Barathi Dassan E.G., Shukur Zainol Abidin M., Anjang A. 2020. Tensile and Compressive Properties of Glass Fiber-Reinforced Polymer Hybrid Composite with Eggshell Powder. Arabian Journal for Science and Engineering, https://doi.org/10.1007/s13369-02004561-z. 